\title{
Multiple Transcriptional Mechanisms Control Ptfla Levels during Neural Development Including Autoregulation by the PTF1-J Complex
}

\author{
David M. Meredith, ${ }^{1}$ Toshihiko Masui, ${ }^{2}$ Galvin H. Swift, ${ }^{2}$ Raymond J. MacDonald, ${ }^{2}$ and Jane E. Johnson ${ }^{1}$ \\ Departments of ${ }^{1}$ Neuroscience and ${ }^{2}$ Molecular Biology, University of Texas Southwestern Medical Center, Dallas, Texas 75390-9111
}

Ptfla, along with an E protein and Rbpj, forms the transcription factor complex PTF1-J that is essential for proper specification of inhibitory neurons in the spinal cord, retina, and cerebellum. Here we show that two highly conserved noncoding genomic regions, a distal $2.3 \mathrm{~kb}$ sequence located $13.4 \mathrm{~kb} 5^{\prime}$ and a $12.4 \mathrm{~kb}$ sequence located immediately $3^{\prime}$ of the Ptfla coding region, have distinct activity in controlling Ptfla expression in all of these domains. The $5^{\prime} 2.3 \mathrm{~kb}$ sequence functions as an autoregulatory element and directs reporter gene expression to all Ptfla domains in the developing nervous system. The autoregulatory activity of this element was demonstrated by binding of the PTF1-J complex in vitro, Ptfla localization to this genomic region in vivo, and the in vivo requirement of Ptfla for the activity of the regulatory element in transgenic mice. In contrast, the $12.4 \mathrm{~kb} \mathrm{3}$ ' regulatory region does not contain any conserved PTF1 sites, and its expression in transgenic mice is independent of Ptf1a. Thus, regulatory information for initiation of Ptfla expression in the developing nervous system is located within the $12.4 \mathrm{~kb}$ sequence 3 ' of the Ptfla gene. Together, these results identify multiple transcriptional mechanisms that control Ptfla levels, one modulating levels by autoregulation through the PTF1-J complex, and the other a Ptfla-independent mechanism for initial activation.

\section{Introduction}

A delicate equilibrium between excitatory and inhibitory neurons is critical for proper nervous system function, and disruption of this balance has been implicated as a cause of pain disorders, epilepsy, and even psychiatric disorders such as schizophrenia (Fields et al., 1991; McCormick and Contreras, 2001; Berry et al., 2003). Ptfla plays a critical role in establishing this balance by promoting GABAergic (inhibitory) cell fates in several regions of the developing nervous system (Glasgow et al., 2005; Hoshino et al., 2005; Fujitani et al., 2006). Furthermore, disruption of Ptfla leads to cerebellar and pancreatic agenesis, respiratory dysfunction, and neonatal lethality in both mice and humans (Krapp et al., 1998; Hoveyda et al., 1999; Kawaguchi et al., 2002; Sellick et al., 2004).

Between embryonic day 10 (E10) and E11.5, six dorsal interneuron progenitor domains (dP1-6) are established in the neural tube, and each expresses a specific basic helix-loop-helix (bHLH) transcription factor [for review, see Caspary and Anderson (2003) and Helms and Johnson (2003)]. Ptfla marks the dP4

Received May 15, 2009; revised July 20, 2009; accepted Aug. 3, 2009.

This work was supported by Public Health Service Grants R01-HD37032 (J.E.J.) and T32-MH076690 (D.M.M.) and Beta-Cell Biology Consortium funding via U19DK42502 (R.J.M.). We thank Dr. Robert Hammer and the outstanding service of the University of Texas Southwestern Transgenic Core Facility for generating the transgenic mice for this study. The Tlx3 antibodies were a generous gift from Drs. T. Müller and C. Birchmeier. We acknowledge Dr. H. Lai, Dr. K. Zimmerman, and Midhat Faroogi for critical comments on the manuscript.

Correspondence should be addressed to Dr. Jane E. Johnson, Department of Neuroscience, University of Texas Southwestern Medical Center, 5323 Harry Hines Boulevard, Dallas, TX 75390-9111. E-mail: jane.johnson@ utsouthwestern.edu.

DOI:10.1523/JNEUROSCI.2303-09.2009

Copyright $\odot 2009$ Society for Neuroscience 0270-6474/09/2911139-10\$15.00/0 population as these cells transition into a postmitotic state and begin to differentiate into mature dI4 interneurons (Glasgow et al., 2005; Mizuguchi et al., 2006). Two additional dorsal interneuron populations, $\mathrm{dIL}^{\mathrm{A}}$ and $\mathrm{dIL}{ }^{\mathrm{B}}$, are born between $\mathrm{E} 11.5$ and E13 (Gross et al., 2002; Müller et al., 2002; Cheng et al., 2004), with Ptfla marking progenitors to the $\mathrm{dIL}^{\mathrm{A}}$ domain $\left(\mathrm{dPL}^{\mathrm{A}}\right)$ (Glasgow et al., 2005; Mizuguchi et al., 2006; Wildner et al., 2006). Ptf1a expression is transient, however, and disappears as progenitors migrate laterally out of the ventricular zone. In the absence of Ptfla, both dI4 and dIL ${ }^{A}$ populations are lost, resulting in a complete loss of GABAergic neurons in the dorsal horn of the spinal cord (Glasgow et al., 2005). The progenitors to these domains do not undergo apoptosis, but instead switch to a glutamatergic (excitatory) identity, revealing a secondary function for Ptfla as repressing the glutamatergic specification program. Ptfla is also expressed in neuronal progenitors in several other regions of the developing CNS. In the cerebellum, Ptf1a is expressed from E12 until shortly after birth in progenitors to Purkinje cells and inhibitory interneurons (Glasgow et al., 2005; Hoshino et al., 2005; Nakhai et al., 2007; Pascual et al., 2007). Ptfla in the retina is expressed during the same period of time, specifying both amacrine and horizontal cells (Fujitani et al., 2006; Nakhai et al., 2007). As with the neural tube domains, both cerebellar and retinal Ptfla populations experience a fate switch to excitatory neurons when Ptfla is lost (Fujitani et al., 2006; Pascual et al., 2007).

Ptfla is a class II bHLH transcription factor that forms a transcriptional complex (PTF1-J) with an E protein and Rbpj (or Rbpjl to form PTF1-L in the adult pancreas) (Cockell et al., 1989; Krapp et al., 1996; Obata et al., 2001; Beres et al., 2006; Masui et al., 2007). The consensus DNA binding site for the PTF1 complex 
includes both an E-box (CANNTG) and an Rbpj site (TC-box), and both are required to activate transcription (Cockell et al., 1989; Rose and MacDonald, 1997; Beres et al., 2006). Importantly, it is the PTF1-J trimer, not the Ptfla/E protein heterodimer, that is essential for function in the developing nervous system and pancreas (Masui et al., 2007; Hori et al., 2008).

Although Ptfla plays a crucial role in specifying inhibitory neurons in a wide variety of neural structures, the mechanisms controlling its expression remain poorly understood. In this study, we identify two distinct mechanisms regulating Ptfla expression in the developing nervous system. A 5' $2.3 \mathrm{~kb}$ element directs reporter gene expression to all Ptf1a domains, is Ptf1adependent, and is a direct target of the PTF1-J complex. Another element encompassing the $12.4 \mathrm{~kb}$ just $3^{\prime}$ of Ptfla also directs reporter expression to most neural Ptfla domains; however, this sequence lacks repressive information restricting its activity both temporally and spatially. Unlike the autoregulatory element, the activity of this $3^{\prime}$ enhancer is independent of Ptfla. Thus, two separable genomic regions code for initiation and positive feedback of Ptfla expression in the developing nervous system.

\section{Materials and Methods}

Description of transgenic constructs. The $5^{\prime} 2.3 \mathrm{~kb}$ enhancer region (chr2: 19351717-19354014) was cloned into the BgEGFP reporter vector (Lumpkin et al., 2003) to generate 2.3Ptfla-GFP or a nuclear lacZ reporter gene with the minimal promoter of the rat Ela1 gene to generate 2.3Ptf1a-lacZ (Masui et al., 2008). A PCR-based site-directed mutagenesis strategy was used to generate mutants in each construct. The precise mutations for each E-box and each TC-box are as shown below in the electrophoretic mobility shift assay (EMSA) probes. All constructs were sequenced to establish their integrity. The 13.4Ptfla5'-lac Z construct contains chr2:19353922-19367481, and the 15.6Ptfla5'-lacZ construct contains chr2:19351717-19367481 placed $5^{\prime}$ to a lacZ reporter gene (Masui et al., 2008). They contain the natural promoter and transcriptional start from the Ptfla gene. The 3' $12.4 \mathrm{~kb}$ enhancer region (chr2: 19369662-19382088) was cloned into a nuclear mCherry reporter vector (with mCherry replacing EGFP in BgEGFP) to generate 12.4Ptf1a$m$ Cherry or a lacZ reporter gene with the minimal promoter of the rat Ela1 gene to generate 12.4Ptf1a-lacZ (Masui et al., 2008). All transgenes contain the bovine growth hormone 3' UTR. Chromosome locations were obtained from the $\mathrm{mm} 9$ assembly. PTF1 sites within the $2.3 \mathrm{~kb}$ and $12.4 \mathrm{~kb}$ regions were identified by scanning conserved regions (obtained from BLAT analysis using http://genome.ucsc.edu/cgi-bin/hgBlat) for E-boxes and TC-boxes in close proximity.

Transgenic mice. Transgenic mice were generated by standard procedures (Brinster et al., 1985) using fertilized eggs from B6SJLF1 (C57BL/ 6JXSJL) crosses. Each transgene was isolated from the recombinant plasmid on a standard agarose gel and microinjected at $1-3 \mathrm{ng} / \mu \mathrm{l}$ into pronuclei of fertilized eggs by the Transgenic Core Facility of University of Texas Southwestern, Dallas. Transgenic embryos and mice were identified by PCR analysis for lacZ, GFP, or mCherry using yolk sac and tail DNA, respectively. For transient transgenic analysis, embryos were assayed at E10.5 for lacZ expression in whole mount (Verma-Kurvari et al., 1996), and subsequently cryosectioned and counterstained with nuclear fast red. 2.3Ptfla-GFP and 12.4Ptf1a-mCherry transgenic mouse strains are stable lines. Ptf1a ${ }^{C r e}\left(p 48^{C r e}\right)$ and Ptf1 ${ }^{W 298 A}$ mutant mouse strains have been previously described (Kawaguchi et al., 2002; Hori et al., 2008). Embryos were staged based on assumed copulation at E0, halfway through the dark cycle.

In ovo chick electroporation. Fertilized White Leghorn eggs were obtained from the Texas A\&M Poultry Department and incubated for $3 \mathrm{~d}$ at $38^{\circ} \mathrm{C}$. Solutions of supercoiled plasmid DNA $(1-4 \mu \mathrm{g} / \mu \mathrm{l})$ in $\mathrm{H}_{2} \mathrm{O} / 1 \times$ loading dye were injected into the lumen of the closed neural tube at stages $\mathrm{HH} 15-16$, and embryos were electroporated as described previously (Nakada et al., 2004). Myc-tagged Ptfla, Ascl1, or the inactive mutant of Ascl1 as control (Ascl1 ${ }^{\mathrm{AQ}}$ ) were overexpressed using a pMiWIII expression vector (Nakada et al., 2004; Hori et al., 2008).
Embryos were harvested $48 \mathrm{~h}$ later at stages $\mathrm{HH} 22-23$, fixed with $4 \%$ paraformaldehyde for $1 \mathrm{~h}$, and processed as below for cryosectioning and immunofluorescence.

Tissue processing and immunofluorescence. Mouse embryos at E10.5 and E12.5 were dissected in ice-cold PBS, fixed in $4 \%$ paraformaldehyde for $2 \mathrm{~h}$ at $4^{\circ} \mathrm{C}$, and washed three times in PBS. E14.5 embryos were fixed in $4 \%$ paraformaldehyde overnight at $4^{\circ} \mathrm{C}$ and washed with PBS overnight. Embryos were then sunk in 30\% sucrose, embedded in OCT, and cryosectioned at $30 \mu \mathrm{m}$. Immunofluorescence was performed with the primary antibodies guinea pig anti-Ptfla (1:5000; Hori et al., 2008), mouse anti-c-myc (1:1000; Santa Cruz Biotechnology), rabbit anti-Pax2 (1:500; Invitrogen), and guinea pig anti-Tlx3 (1:20,000) (Müller et al., 2005).

EMSAs. Mouse E12, mouse Ptfla, and human Rbpj proteins were synthesized in vitro using SP6 and T7 TNT Quick Coupled lysate systems (Promega). TNT lysates were incubated in binding buffer (10 mM HEPES, pH 7.9, 4 mM Tris- $\mathrm{HCl}, \mathrm{pH}$ 8.0, $80 \mathrm{~mm} \mathrm{NaCl}, 1 \mathrm{~mm}$ EDTA, 5\% glycerol, $5 \mathrm{~mm}$ DTT, $6 \mu \mathrm{g}$ of BSA, and $2 \mu \mathrm{g}$ of Poly dI/dC) along with a $\left({ }^{\gamma-32} \mathrm{P}\right)$ end-labeled oligo probe $(50,000 \mathrm{cpm})$ in a total volume of $20 \mu \mathrm{l}$ for $30^{\circ} \mathrm{C}$ for $30 \mathrm{~min}$. Reactions were transferred to ice for $15 \mathrm{~min}$ before loading. Complexes were separated on a $4.5 \%$ polyacrylamide matrix gel at $4^{\circ} \mathrm{C}$ in $1 \times$ TGE. The following oligonucleotides were used as labeled probes in EMSA: proximal (P) PTF1 site: 5'-CCCAGCACATGTGTTATGATTCCCACGGACTG-3' (top strand); distal (D) PTF1 site: 5'-AGCGGCACAAGTGGCGACATTCCCATGGAGCG-3' (top strand); E-box mutant of $\mathrm{P}$ site: 5'CCCAGtACtataGTTATGATTCCCACGGACTG-3' (top strand); E-box mutant of D site: 5' -AGCGGtACtAtaGGCGACATTCCCATGGAGCG-3' (top strand); TC-box mutant of the P site: 5'-CCCAGCACATGTGTTATGATTCaatCGGACTG-3' (top strand); and TC-box mutant of the D site: 5'-AGCGGCACAAGTGGCGACATTCtatTGGAGCG-3' (top strand).

Chromatin immunoprecipitation. Neural tubes were collected from E11.5 mouse embryos and dissociated in PBS at low speed using an IKA model T8.01 probe blender. Formaldehyde was added to a final concentration of $1 \%$, and dissociated tissue was incubated for $10 \mathrm{~min}$ at room temperature. The fixation reaction was stopped by adding glycine to a final concentration of $0.125 \mathrm{~m}$ followed by washing twice with PBS. Nuclei were obtained using a CelLytic NuCLEAR Extraction Kit (Sigma). Chromatin was enzymatically sheared to an average length of 800-1000 bp using Active Motif's ChIP-IT Express Kit. ChIP was performed as described previously (Masui et al., 2007) using protein-A agarose beads (Millipore). DNA was purified from each reaction using QIAQuick purification columns (Qiagen) and quantified by qPCR with Fast SYBRGreen mix (ABI). Percentage ChIP efficiency equals $2^{\text {(Threshold Cycle Input }- \text { Threshold Cycle ChIP) }} \times 1$ /dilution factor $\times 100$. Fold enrichment is shown relative to a control gene Mrps15. The following primers were used for qPCR: distal PTF1 site: forward (F), 5'-CTGACACTAATAGCTCGCGGCTCAGGTACG-3'; reverse (R), 5'-AGGCTGTTTCAAAAGGCGACACCTGCAAGC-3'; proximal PTF1 site: F, 5'-AGCCAGGTGTCCCCAATGTACCTTTGAGGA-3'; R, 5'-GGTGTTCAGACGCTCGGGGAAATCAGGCA-3'; Mrps15: F, 5'-CTGGGACATAGTGGGTGCTT-3'; R, 5'-GAGCCTAGAGATGGGCTGTG-3'; control region C1: F, 5' -TCTTCACCCAGCACTCAGGCTC-3'; R, 5'-ATCCTGATGGTTCCCATGGCCACTTTCG-3'; control region C2: F, 5'-TCATAAGCCCATGCCAACCCTG-3'; R, 5'-GCCATATGTGTTTGCTCATTTTGCGCTCC-3' .

\section{Results}

\section{Two regulatory sequences direct $P t f 1 a$-specific expression in} the neural tube

To begin to understand how Ptfla is regulated, we searched the $30 \mathrm{~kb}$ genomic region surrounding the mouse Ptfla gene for evolutionary conserved regions that might function as cisregulatory elements using BLAT analysis for 28 vertebrate species (http://genome.ucsc.edu/cgi-bin/hgBlat). Several sequences within this region were identified that display extensive conservation throughout vertebrates including a $15.6 \mathrm{~kb}$ sequence lying immediately $5^{\prime}$ of Ptfla coding region and a $12.4 \mathrm{~kb}$ sequence immediately $3^{\prime}$ (Fig. $1 F$ ). These sequences were assayed for activity in directing Ptfla-specific expression using a heterologous lac $Z$ reporter gene in transgenic mouse embryos at embryonic 


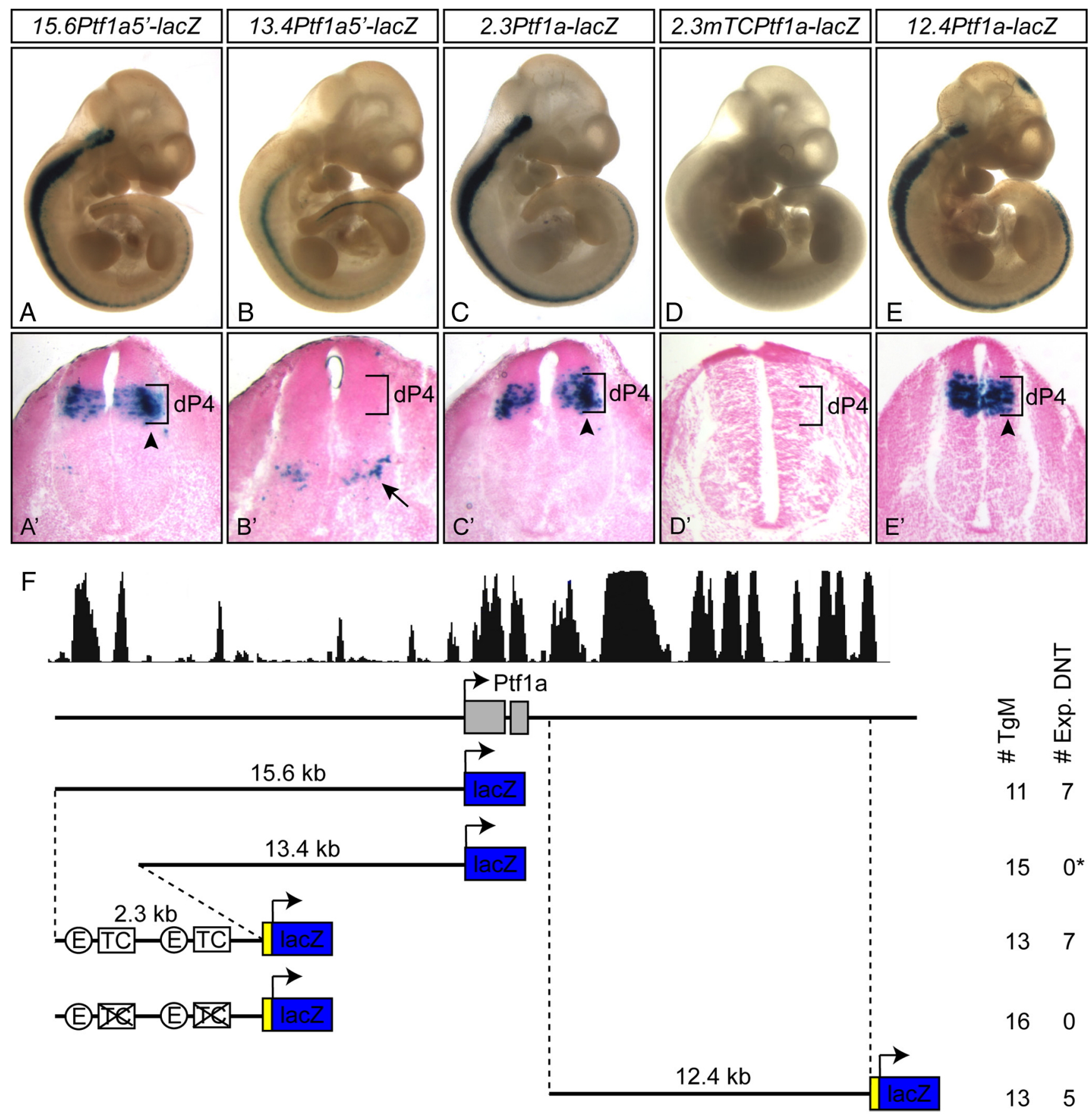

Figure 1. Identification of sequences regulating Ptf1a expression. $\boldsymbol{A}-\boldsymbol{E}$, Representative transgenic E10.5 mouse embryos $\beta$-gal stained as whole mounts. $\boldsymbol{A}^{\prime}-\boldsymbol{E}^{\prime}$, Cross sections of the $\beta$-galstained embryos showing the neural tube taken at the forelimb level. The bracketed area indicates the region where endogenous Ptf1a is expressed (dP4). $A-C$, The $2.3 \mathrm{~kb}$ region appears to be both necessary within the $15.6 \mathrm{~kb}$ enhancer, and sufficient when tested on a heterologous promoter (Ela 1) to direct dorsal expression. $\boldsymbol{D}, \boldsymbol{D}^{\prime}$, Mutating the TC-box in both PTF1 sites in the $2.3 \mathrm{~kb}$ enhancer destroys expression. $\boldsymbol{E}$, The $3^{\prime} 12.4 \mathrm{~kb}$ region also directs dorsal-specific expression. Expression in the midbrain does not reflect normal Ptf1a expression. Arrowheads in $\boldsymbol{A}^{\prime}, \boldsymbol{C}^{\prime}$, and $\boldsymbol{E}^{\prime}$ indicate the enriched $\beta$-gal signal at the lateral edge of the ventricular zone seen with the $5^{\prime}$ but not the $3^{\prime}$ regulatory sequences. $\boldsymbol{F}$, Top, Graphical representation of the sequence conservation ( -16.5 kb to $+15.5 \mathrm{~kb}$ ) surrounding Ptf1a across 28 vertebrate species using BLAT (http://genome.ucsc.edu/cgi-bin/hgBlat). Bottom, Diagram of transgenes used with respect to the Ptf1a locus and the corresponding number of embryos expressing LacZ in the dorsal neural tube (DNT) out of those positive for the transgene (TgM). ${ }^{*}$ Expression in neural tube is ventral and does not reflect the Ptf1a pattern $\left(\boldsymbol{B}, \boldsymbol{B}^{\prime}\right.$, arrow). The yellow filled area represents the Ela1 basal promoter that does not function on its own to activate reporter expression (Beres et al., 2006).

day 10.5 (E10.5). Both sequences were sufficient in transgenic embryos to direct lac $Z$ expression to the dorsal neural tube from hindbrain regions to the tail (Fig. $1 A, E)$. $\beta$-Galactosidase ( $\beta$-gal) staining was restricted within the dorsal neural tube in a domain consistent with known Ptfla expression in progenitors to dI4 interneurons (dP4) (Fig. 1 $A^{\prime}, E^{\prime}$ ). Although both the $5^{\prime}$ and $3^{\prime}$ regulatory sequences direct expression to the $\mathrm{dP} 4$ domain, there is a subtle difference in the pattern in the medial lateral axis. $\beta$-gal staining from the $5^{\prime}$ sequence is enriched in the lateral edge of the ventricular zone, whereas expression from the $3^{\prime}$ sequence is somewhat uniform throughout the ventricular zone (Fig. $1 A^{\prime}, E^{\prime}$, arrowheads). The distinct pattern of reporter expression suggests that these elements are not redundant but rather that they play different roles in Ptfla regulation. 


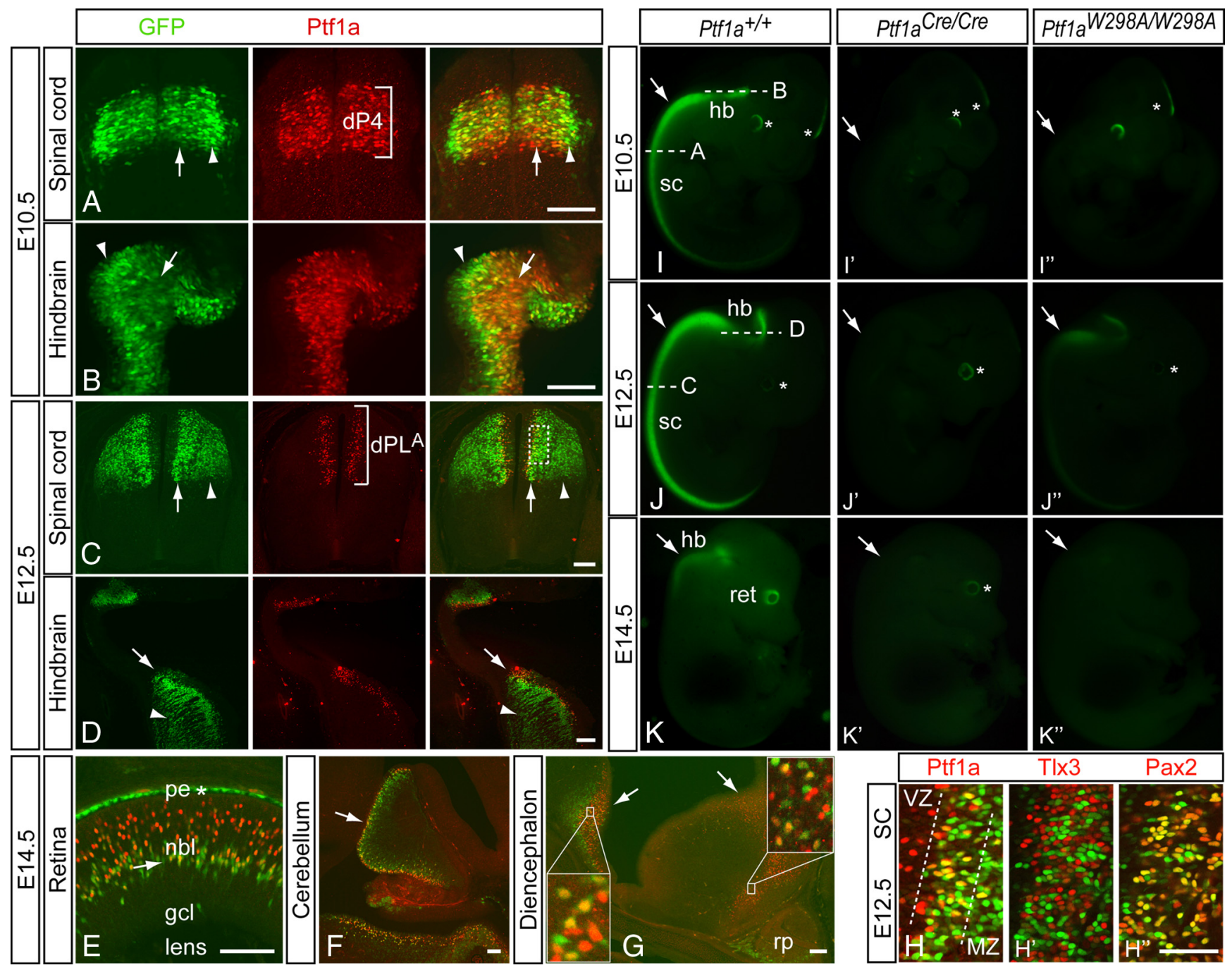

Figure 2. Activity of the $2.3 \mathrm{~kb}$ regulatory element in transgenic mice. $A-D$, At E10.5 and E12.5, GFP fluorescence (green) strongly colabels with Ptfla immunofluorescence (red) in the spinal cord $(\mathrm{sc})$ and hindbrain (hb) (arrows) in the 2.3Ptf1a-GFP transgenic mouse strain. The GFP persists in cells that have begun to migrate away from the ventricular zone and have downregulated Ptf1a (arrowheads). E-G, Sagittal sections of Ptf1a-expressing domains at E14.5. E, At E14.5, when it is most strongly expressed in the retina, Ptf1a is confined to the neuroblastic layer (nbl). GFP from 2.3Ptf1a-GFP is similarly restricted, but colabeling with Ptf1a is most prominent at the inner portion of this layer (arrow), where more mature cells have migrated. *Ectopic expression in the pigmented epithelium (pe). $\boldsymbol{F}, 2.3$ Ptf1a-GFP expression closely mimics Ptf1a in both the cerebellum (arrow) and rostral hindbrain. $\mathbf{G}$, Ptf1a can be detected in two regions within the developing hypothalamus (arrows), and GFP signal can be detected in both areas (insets), though it is more abundant in the anterior domain. $\boldsymbol{H}$, High magnification of region indicated by dashed box in $\boldsymbol{C}$. GFP colabels with Ptf1a (between the dashed lines) at the lateral edge of the ventricular zone (VZ) and is maintained as Ptf1a-expressing cells mature and migrate into the mantle zone (MZ). No GFP is detected in the medial ventricular zone. $\boldsymbol{H}^{\prime}, \boldsymbol{H}^{\prime \prime}$, T|x3 immunofluorescence (red) $\left(\boldsymbol{H}^{\prime}\right)$ does not colabel with GFP, whereas Pax2 immunofluorescence (red) ( $\left.\boldsymbol{H}^{\prime \prime}\right)$ colabels strongly with GFP. $\boldsymbol{I}-\boldsymbol{K} \boldsymbol{i}$ Representative embryos from a 2.3Ptf1a-GFP transgenic line at E10.5, E12.5, and E14.5 in both wild-type and Ptf1a mutant backgrounds. The dotted lines indicate the section plane for $\boldsymbol{A}-\boldsymbol{D}$. Transgene expression reflects the pattern of endogenous Ptf1a in the dorsal neural tube from the hindbrain caudally to the tail. The expression in the retinal pigmented epithelium and the midbrain marked by asterisks in $/$ and $J$ represent ectopic activity of the $2.3 \mathrm{~kb}$ regulatory element as $P t f 1 a$ is not expressed in these tissues. Transgene expression in the neural tube is absent in the $P t f 1 a$ null $\left(\boldsymbol{I}^{\prime}-\boldsymbol{K}^{\prime}\right.$, arrow) and markedly diminished in the $P t f 1 a^{W 298 A} / W 298 A$ mutant $\left(\boldsymbol{I}^{\prime \prime}-\boldsymbol{K}^{\prime \prime}\right.$, arrow), while the ectopic expression in the retina and midbrain is unaffected (asterisks). gcl, Ganglion cell layer; ret, retina; rp, Rathke's pouch. Scale bars: $\boldsymbol{A}-\boldsymbol{G}, 100 \mu \mathrm{m} ; \boldsymbol{H}, 50 \mu \mathrm{m}$.

A conserved distal 5' $2.3 \mathrm{~kb}$ enhancer is a direct PTF1-J targeted autoregulatory element

Activity of the $2.3 \mathrm{~kb}$ Ptfla $5^{\prime}$ enhancer

The most distal $2.3 \mathrm{~kb}$ of the $15.6 \mathrm{~kb}$ sequence contains the highest conservation (Fig. 1). When tested in isolation, the distal 2.3 $\mathrm{kb} 5$ ' region exhibited the same restricted dorsal neural tube expression seen with the full $15.6 \mathrm{~kb}$ region (Fig. $1 C$ ). In contrast, the intervening proximal $13.4 \mathrm{~kb}$ region had no activity in directing expression to the dorsal neural tube (Fig. $1 B$ ). It did, however, consistently direct expression to a ventral neural tube pattern ectopic to the normal Ptfla pattern (Fig. $1 B^{\prime}$, arrow). Thus, the $2.3 \mathrm{~kb}$ sequence possesses the activity for directing reporter gene expression to the $\mathrm{dP} 4$ region in the dorsal neural tube and information for repressing ventral neural tube activity of the proximal $13.4 \mathrm{~kb}$ sequence.
Because Ptfla is expressed in several regions in the developing nervous system at multiple embryonic stages, we generated independent transgenic mouse lines with the $2.3 \mathrm{~kb}$ regulatory element driving nuclear GFP (2.3Ptf1a-GFP) and characterized reporter gene expression at multiple stages. Two separate 2.3Ptfla-GFP mouse strains were identified that directed expression of GFP to all Ptfla domains in a similar manner. All images shown are from one of these lines (Fig. 2). 2.3Ptfla-GFP expresses strongly in the dorsal neural tube and hindbrain at E10.5 (Fig. $2 A, B, I$ ), consistent with the 2.3Ptfla-lacZ transgenic embryos (Fig. 1C). This expression persisted through E12.5, but by E14.5 levels were significantly diminished (Fig. 2 J, K; supplemental Fig. $1 A$, available at www.jneurosci.org as supplemental 


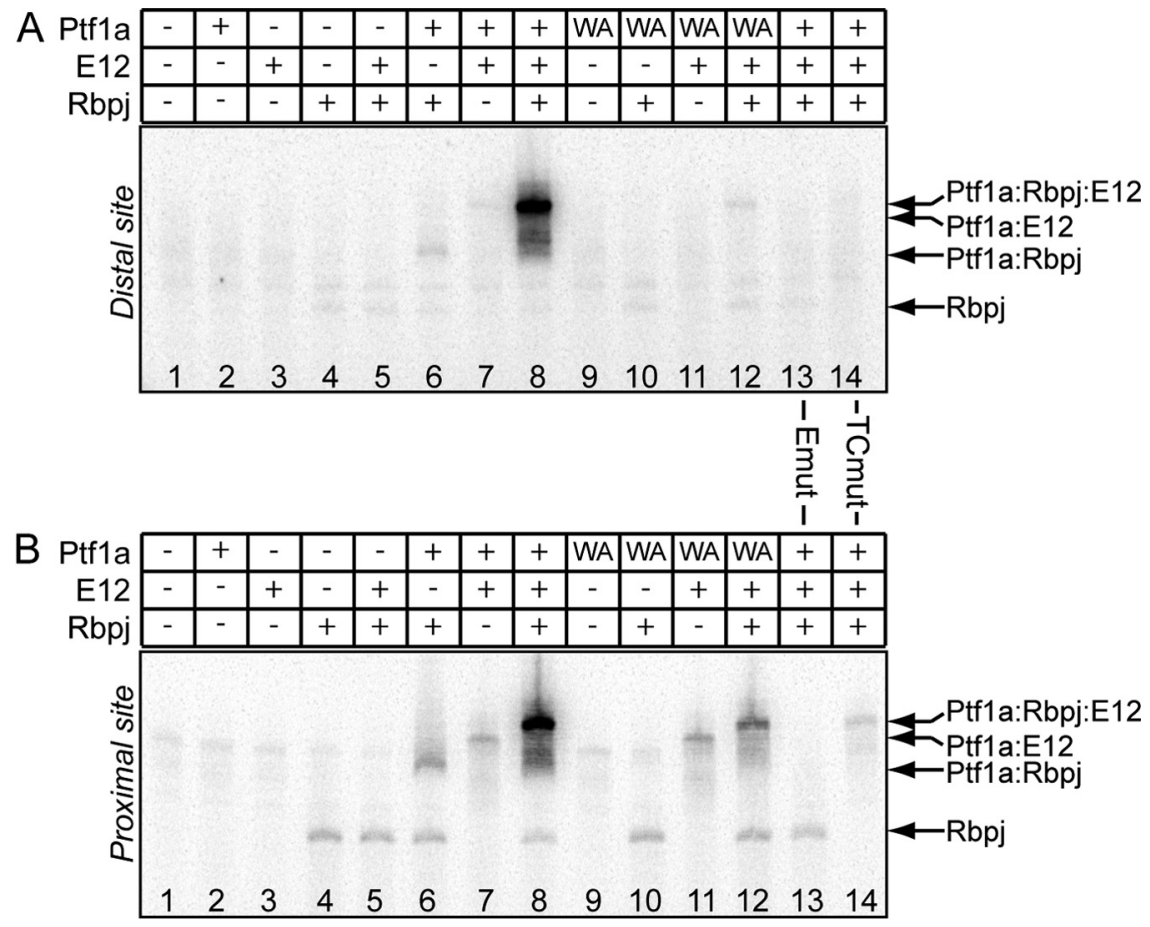

Figure 3. PTF1-J binds to the proximal and distal PTF1 sites within the $2.3 \mathrm{~kb}$ regulatory region. EMSA with each PTF1 site from the $2.3 \mathrm{~kb} 5$ ' regulatory region. $\boldsymbol{A}$, The distal site is bound by the PTF1-J trimer that includes Ptf1a, E12, and Rpbj (lane 8). Neither the Ptf1a:E12 heterodimer nor Rbpj alone bind strongly to this site (lanes 4, 7). Substitution of the Ptf1a ${ }^{\text {W298A }}$ mutant (WA) for Ptfla strongly disrupts the interaction with Rbpj (compare lanes 6 and 8 with 10 and 12). Both E-box and TC-box mutations prevent trimer binding (lanes 13, 14). B, The proximal site is bound not only by PTF1-J (lane 8), but also by Rbpj (lane 4), Ptf1a:Rbpj (lane 6), and Ptf1a:E12 (lane7). As with the distal site, Ptf1a ${ }^{\text {W298A }}$ disrupts binding of PTF1-J and Ptf1a:Rbpj (lanes 10, 12). Disruption of either the E-box or TC-box prevents PTF1-J trimer binding (lanes 13, 14). The E-box mutation does not, however, affect Rbpj binding.
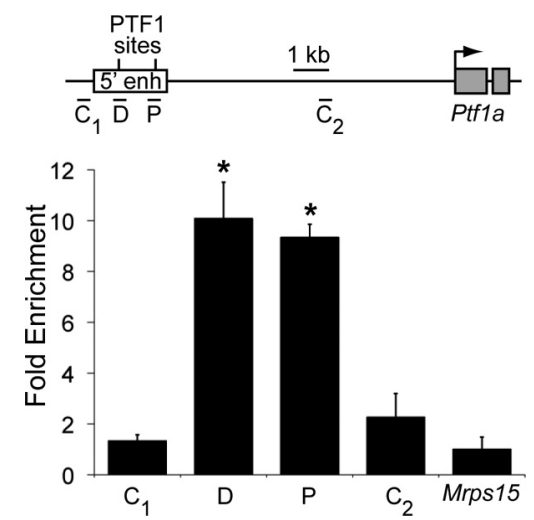

Figure 4. Ptf1a occupies the $2.3 \mathrm{~kb} 5^{\prime}$ regulatory region in vivo. ChIP was performed with antibodies against Ptf1a using chromatin from E11.5 mouse neural tube. Both proximal and distal PTF1 sites (P, D) are enriched relative to a control gene Mrps15, while control regions flanking these sites are not enriched (C1, C2). Top, Location of qPCR products within the Ptf1a locus. Error bars represent SDs. ${ }^{*} p<0.01$.

material). A comparison of GFP with endogenous Ptfla demonstrated extensive overlap in the $\mathrm{dP} 4$ and $\mathrm{dPL}^{\mathrm{A}}$ progenitor domains in the developing spinal cord at E10.5 and E12.5, respectively (Fig. $2 A, C$ ). This overlap extends rostrally through hindbrain regions as well (Fig. $2 B, D$ ). Although the expression domains align precisely in the dorsal/ventral and rostral/caudal axes, GFP expression appears to be slightly delayed relative to Ptfla, as the overlap is restricted to the lateral edge of the Ptfla domain (Fig. $2 \mathrm{H}$ ). Furthermore, GFP is enriched lateral to the ventricular zone where Ptfla lineage cells migrate as they lose Pftla and differentiate
(Fig. 2A-D, arrows vs arrowheads). This pattern most likely reflects differences in stability of GFP versus Ptfla.

This property allowed us to conduct short term lineage tracing to verify that the $2.3 \mathrm{~kb}$ regulatory element is exclusively active in Ptfla-expressing precursors. Tlx3, which specifically marks glutamatergic neurons from the dI3, dI5, and dIL $^{\mathrm{B}}$ domains (Cheng et al., 2004, 2005), does not overlap with GFP in the neural tube at either E10.5 (data not shown) or E12.5 (Fig. $2 H^{\prime}$ ). However, Pax2, which specifically marks GABAergic neurons from dI4 and dIL ${ }^{\mathrm{A}}$ in the dorsal neural tube, colabels strongly with GFP at E10.5 (data not shown) and almost completely at E12.5, with only immature GFP-positive cells in the ventricular zone not yet expressing Pax2 (Fig. $2 H^{\prime \prime}$ ).

By E14.5, pronounced Ptfla expression can be seen in the developing retina, cerebellum, and diencephalon (Fujitani et al., 2006; Pascual et al., 2007). GFP from the transgene mimics Ptfla expression in the neural retina, as it can be first detected at E12.5 (data not shown) and is readily seen in the neuroblastic layer by E14.5 (Fig. 2E). Similarly, strong overlap between Ptfla and GFP is detected in the cerebellum and hindbrain (Fig. $2 F$ ). In the diencephalon, Ptfla is in two domains that will give rise to the preoptic and ventral medial regions of the hypothalamus (Glasgow et al., 2005) (Fig. 2G). The GFP reporter is detected in the preoptic Ptfla domain and weakly in the posterior domain. Weak GFP signal is also present in the dorsal spinal cord at this stage; however, this is most likely due to GFP persistence, as Ptfla levels and overall GFP are greatly reduced (supplemental Fig. $1 A$, available at www.jneurosci.org as supplemental material). Thus, the distal $2.3 \mathrm{~kb} 5^{\prime}$ enhancer is active in all Ptfla-expressing regions of the developing nervous system.

\section{Two PTF1 binding sites are present in the $2.3 \mathrm{~kb}$ Ptfla regulatory sequence}

Sequence analysis of the two highly conserved peaks in the $2.3 \mathrm{~kb}$ enhancer revealed the presence of two PTF1 binding sites, referred to here as the proximal (P) and the distal (D) PTF1 sites (Masui et al., 2008). Each PTF1 site contains an E-box, a $5 \mathrm{nt}$ spacer, and a TC-box, thus adhering to the consensus sequence (Beres et al., 2006). Using EMSAs, we demonstrated that the PTF1-J trimer complex efficiently binds both these sites (Fig. $3 A, B$, lane 8 ). The two sites have somewhat different properties in that the P site E-box can be bound by a Ptfla:E12 dimer and by Rbpj monomer (Fig. 3B, lanes 4,7), whereas binding of these components to the $\mathrm{D}$ site is minor (Fig. $3 A$, lanes 4,7 ). A mutant of Ptfla, Ptf1a ${ }^{\text {W298A }}$, that does not efficiently interact with Rbpj (Beres et al., 2006; Hori et al., 2008), does not efficiently form a trimer complex with either PTF1 site (Fig. $3 A, B$, lane 12). Furthermore, mutating the E-box in either of these sites destroys binding of the PTF1-J trimer as well as the Ptfla:E12 dimer but does not disturb the Rbpj monomer (Fig. 3A,B, lane 13). Similarly, the TCbox mutations also disrupt trimer binding, in addition to preventing Rbpj monomer from binding (Fig. 3B, lane 14). 


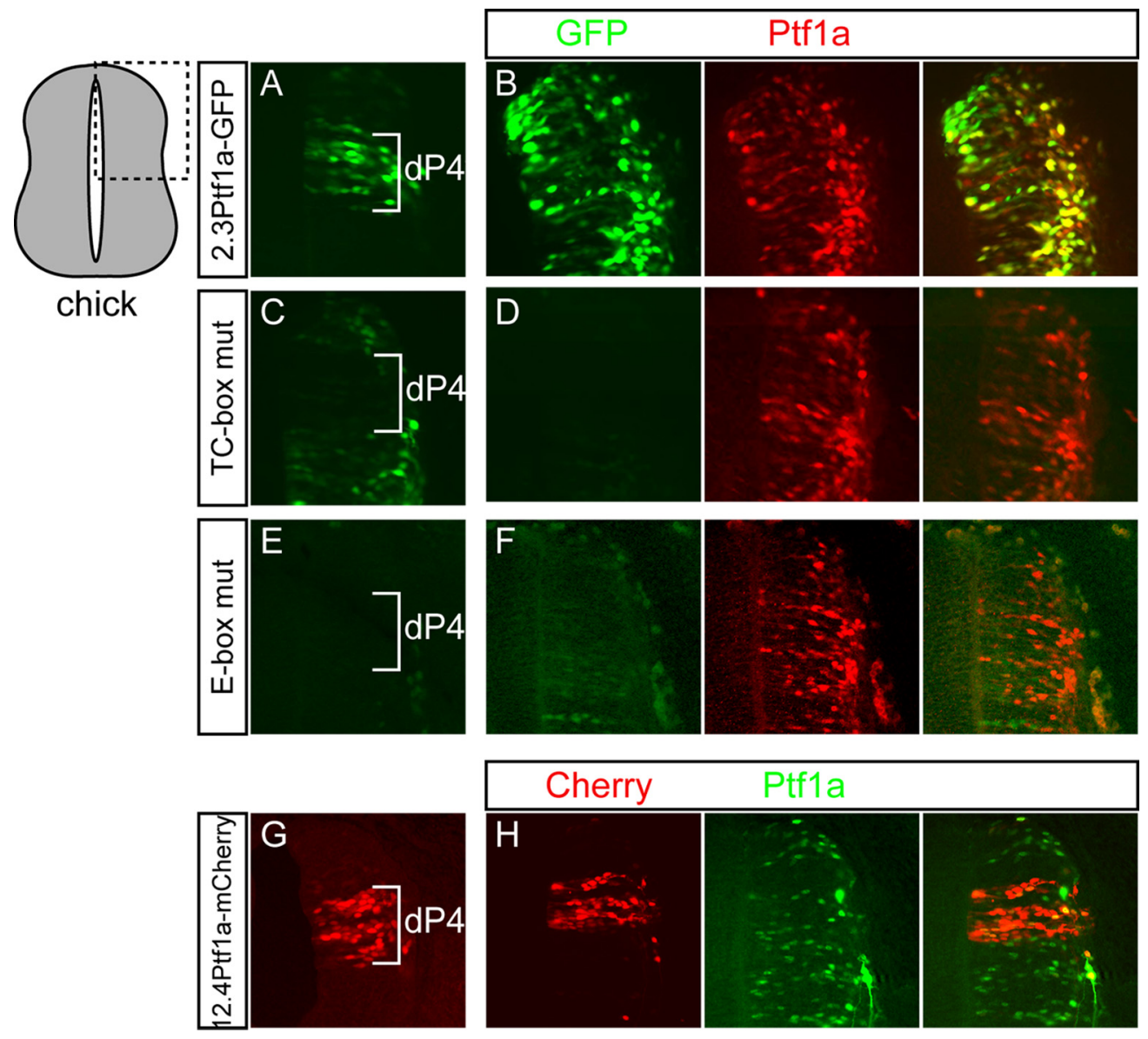

Figure 5. Ptf1a induces activity of the $2.3 \mathrm{~kb}$ Ptf1a regulatory region in the chick neural tube. $\boldsymbol{A}$, The mouse 2.3Ptf1a-GFP construct was electroporated into chick neural tubes at HH15-16 and assayed $48 \mathrm{~h}$ later. GFP was restricted dorsally to what appears to be the $\mathrm{dP} 4 / \mathrm{d} \mid 4$ region. B, Coelectroporation of a Ptf1a expression vector with the 2.3Ptfla-GFP results in ectopic reporter expression (green). This response is cell autonomous as detected by colabeling of GFP fluorescence with Ptf1a immunofluorescence (red) (antibody recognizes electroporated mouse Ptf1a only). C, E, Mutating the TC-boxes $(\boldsymbol{C})$ or the E-boxes $(\boldsymbol{E})$ in both PTF1 sites in the $2.3 \mathrm{~kb}$ regulatory region destroys the ability of the region to drive dorsal expression. $\boldsymbol{D}, \boldsymbol{F}$, Misexpression of Ptf1a does not induce ectopic reporter expression through either of these mutant enhancers. $\mathbf{G}, \boldsymbol{H}$, The mouse $12.4 \mathrm{Ptf1a}$-mCherry construct similarly expresses in the $\mathrm{dP} 4 / \mathrm{dl} 4$ region. Ectopic expression of Ptf1a does not alter expression from this transgene.

EMSAs demonstrate the two PTF1 sites within the $2.3 \mathrm{~kb} 5^{\prime}$ enhancer can be bound by the PTF1-J transcription complex in vitro. To verify that Ptfla binds to this genomic region in vivo, we performed chromatin immunoprecipitation (ChIP) with E11.5 neural tubes using antibodies against Ptfla (Beres et al., 2006). Genomic regions containing the P or D PTF1 sites were enriched $\sim 10$-fold relative to a control genomic region in the Mrps 15 gene (encodes a $28 \mathrm{~S}$ subunit protein) (Fig. 4). Neither of two control Ptfla genomic regions $>1 \mathrm{~kb}$ away from the PTF1 sites showed significant enrichment (Fig. 4). Together these results provide evidence for direct autoregulation of the $2.3 \mathrm{~kb} 5^{\prime}$ enhancer by Ptfla itself as a component of the PTF1-J transcription complex.

Activity of the $2.3 \mathrm{~kb} 5^{\prime}$ enhancer requires the PTF1 sites

We next examined the requirement for the PTF1 sites within the 2.3 kb 5' Ptfla enhancer for enhancer activity. The TC-box in each site was mutated, and the resulting mutant enhancer was tested in a lac $Z$ reporter in transgenic mouse embryos. The TC-box mutations completely destroyed activity of the enhancer, and no lac $Z$ reporter was detected in 16/16 transgenic embryos (Fig. $1 D, D^{\prime}$ ).

To further investigate the PTF1 site sequence requirements for activity of the enhancer, we moved to the in ovo chick electroporation assay. When electroporated into chick neural tubes at HH15-16 and assayed $48 \mathrm{~h}$ later, the $2.3 \mathrm{~kb} 5^{\prime}$ enhancer gave restricted GFP expression in the dorsal neural tube, similar to that seen in transgenic mouse embryos with the same transgene (compare Fig. $5 A$ with Fig. $2 A$ ). Coelectroporation of a Ptfla expression vector with the $2.3 \mathrm{~kb} 5^{\prime}$ enhancer induced GFP reporter expression throughout the neural tube in cells expressing the ectopic Ptfla (Fig. 5B), indicating that Ptfla is sufficient to activate expression through this enhancer in a cell-autonomous manner. This is not a general response to expression of bHLH factors since coelectroporation with Ascl1 does not activate enhancer activity (supplemental Fig. 2, available at www.jneurosci. org as supplemental material). E-box and TC-box mutant $2.3 \mathrm{~kb}$ enhancer reporters disrupted the ability of the enhancer to direct expression to the dorsal neural tube (Fig. 5, compare $C$ and $E$ with $A)$. Furthermore, both the E-box and TC-box mutant enhancers were unresponsive to ectopic Ptfla (Fig. 5, compare $D$ and $F$ with $B)$. These two sets of mutations highlight the importance of both halves of the PTF1 sites to the $2.3 \mathrm{~kb}$ enhancer function, showing that it is the activity of PTF1-J complex, and not any of its subcomponents (Ptfla:E12 dimer or Rbpj monomer), that is necessary for activity of the $2.3 \mathrm{~kb} \mathrm{5'Ptfla} \mathrm{enhancer.}$

Activity of the $2.3 \mathrm{~kb}$ enhancer in vivo requires Ptfla and its interaction with $\mathrm{Rbpj}$

Our results strongly support direct positive autoregulation through the PTF1 sites as the mechanism of action for the $2.3 \mathrm{~kb}$ 5' Ptfla enhancer. To lend further in vivo support, we examined 


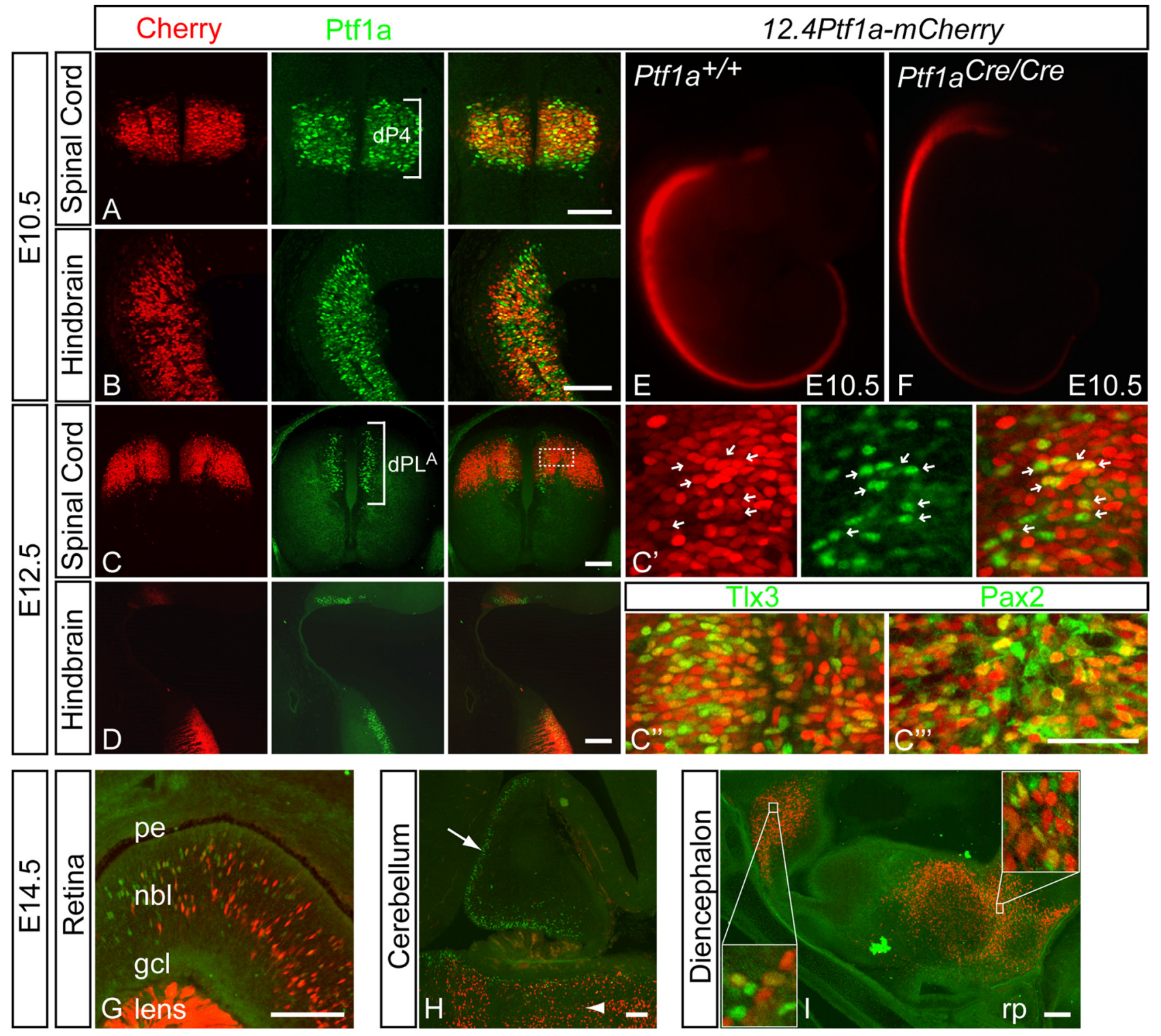

Figure 6. Activity of the $3^{\prime} 12.4 \mathrm{~kb}$ regulatory region in transgenic mice. $A, B, A t$ E10.5, fluorescence from the mCherry reporter (red) strongly colabels with Ptfla immunofluorescence (green) in the spinal cord and hindbrain in the 12.4Ptf1a-mCherry transgenic mouse strain. $C, D, B y E 12.5$, mCherry expression continues to overlap Ptf1a in the hindbrain and in $\mathrm{PPL}^{\mathrm{A}}$ progenitors in the spinal cord; however, it has now expanded laterally beyond the ventricular zone in both regions. $\boldsymbol{C}^{\prime}, \boldsymbol{C}^{\prime \prime}, \boldsymbol{C}^{\prime \prime}$, Higher magnification of region indicated by dashed box in $\boldsymbol{C}^{\prime} \boldsymbol{C}^{\prime}$, mCherry labels many more cells than does Ptfla in the ventricular zone. Also, cells that express Ptf1a appear to have less mCherry signal (arrows). mCherry colabels with both Tlx3 ( $\left.\boldsymbol{C}^{\prime \prime}\right)$ and Pax2 (C'") immunofluorescence. $\mathbf{G}-\mathbf{I}$, Sagittal sections of Ptf1a-expressing domains at E14.5. G, 12.4Ptf1a-mCherry expression overlaps Ptf1a in the neuroblastic layer of the retina (nbl), and it ectopically expresses in the lens. $\boldsymbol{H}$, Reporter signal is absent from the cerebellum (arrow), while hindbrain expression continues to persist beyond the Ptf1a-positive region (arrowhead). $I$, mCherry signal overlaps Ptf1a in both hypothalamic regions (insets), although the reporter expression is not limited to Ptf1a-expressing cells. $E$, Representative E10.5 embryo from a 12.4Ptf1a-mCherry transgenic line. Transgene expression reflects the pattern of endogenous Ptf1a in the dorsal neural tube from the hindbrain caudally to the tail. $F$, E10.5 embryo from the 12.4Ptf1a-mCherry line shown in $\boldsymbol{E}$ crossed onto Ptf1a-null background. Unlike 2.3Pff1a-GFP, 12.4Ptf1a-mCherry expression is unaffected in the Ptfla mutant. gcl, Ganglion cell layer; pe, pigmented epithelium; rp, Rathke's pouch. Scale bars: $A-D, G-I, 100 \mu \mathrm{m} ; \boldsymbol{C}^{\prime}, \boldsymbol{C}^{\prime \prime}, \mathbf{C}^{\prime \prime}, 50 \mu \mathrm{m}$.

enhancer activity of the 2.3Ptf1a-GFP transgene in mice null for Ptfla or mice with the mutant Ptf1 $a^{W 298 A}$ allele. In Ptf1a-null embryos, GFP expression was completely absent in all Ptfla domains at E10.5, E12.5, and E14.5 (Fig. $2 I^{\prime}-K^{\prime}$ ). The only expression that remained was ectopic expression from the transgene seen in the retina pigmented epithelium and the midbrain (Fig. $2 I^{\prime}-K^{\prime}$, asterisks). In the Ptf1a ${ }^{W 298 A}$ mutants, where the single amino acid mutant in Ptfla disrupts its ability to form a complex with Rbpj (Beres et al., 2006; Hori et al., 2008), GFP expression was also dramatically reduced from wild-type levels (Fig. $2 I^{\prime \prime}-K^{\prime \prime}$ ). In contrast to expression of the transgene in the Ptfla null, there were a few cells in each Ptfla domain that retained GFP expression. This was most apparent in the spinal cord at E12.5 (Fig. $2 J^{\prime \prime}$ ).
This incomplete loss of enhancer activity with the Ptff1a W298A mutant may reflect low levels of functional PTF1-J complex that may form (Fig. 3A, B, lane 12) (Beres et al., 2006). Nonetheless, these findings demonstrate the necessity for Ptfla and its interaction with Rbpj for autoregulation through the $2.3 \mathrm{~kb}$ enhancer.

\section{The conserved 3' $12.4 \mathrm{~kb}$ sequence contains cis-regulatory} information for activation of Ptfla expression

Transgenic analysis demonstrated that the $12.4 \mathrm{~kb}$ sequence just $3^{\prime}$ of the Ptfla coding region can function to direct specific expression of Ptfla in the dorsal neural tube in the dP4 domain (Fig. $1 E)$. As we did for the $5^{\prime}$ enhancer, we generated independent transgenic mouse lines with the $12.4 \mathrm{~kb}$ regulatory element driv- 
ing a nuclear-localized mCherry reporter (12.4Ptfla-mCherry) and characterized reporter gene expression at multiple stages. Three separate 12.4Ptf1a-mCherry lines were identified that expressed mCherry similarly in Ptfla domains (Fig. 6). As with the 12.4Ptf1a-lacZ transgenic embryos (Fig. 1E), the 12.4Ptf1a$m$ Cherry transgene expresses strongly in the $\mathrm{dP} 4$ domain of the dorsal neural tube and hindbrain at E10.5 (Fig. 6A, B). mCherry was compared with endogenous Ptfla using immunofluorescence, revealing extensive overlap in these regions (Fig. 6A,B). However, the mCherry signal is more uniformly intense and labels more cells than does Ptf1a. Analysis at E12.5 showed similar results; mCherry continues to overlap Ptfla in the $\mathrm{dPL}^{\mathrm{A}}$ progenitor domain in the developing spinal cord, as well as in the hindbrain (Fig. 6C,D). In contrast to $2.3 P t f 1 a-G F P$, mCherry densely labels the dorsal ventricular zone, including many cells that have yet to activate Ptfla (Fig. $6 C^{\prime}$ ); however, the dorsoventral extent of expression is more restricted (compare Fig. $2 C$ with Fig. $6 C$ ). Interestingly, those cells that express Ptfla seem to have lower levels of mCherry (Fig. 6C', arrows). By this point however, mCherry persists well beyond Ptfla, labeling mature neurons that have migrated laterally away from the ventricular zone. As with 2.3 Ptfla-GFP, this permitted us to determine the identities of mature mCherry-positive neurons. In contrast with the $2.3 \mathrm{~kb}$ enhancer, the $12.4 \mathrm{~kb}$ enhancer is active in both $\mathrm{dIL}^{\mathrm{A}}$ and $\mathrm{dIL}^{\mathrm{B}}$ progenitors, as mCherry colabels equally with Tlx 3 and Pax 2 in the E12.5 neural tube (Fig. $6 C^{\prime \prime}, C^{\prime \prime}$ ). Although the expression domains align precisely in the dorsal/ventral and rostral/caudal axes, there are distinct and important differences in the mCherry and Ptfla expression patterns at the cellular level.

Along with Ptfla, the $3^{\prime} 12.4 \mathrm{~kb}$ enhancer expresses weakly in the neural retina beginning at E12.5 (data not shown), with prominent mCherry signal detectable at E14.5 (Fig. 6G). Ectopic signal in the lens is also detected (Fig. 6G). The $3^{\prime} 12.4 \mathrm{~kb}$ sequence also directs expression to both Ptfla-expressing domains in the hypothalamus at E14.5 (Fig. 6I), although its expression is much more robust in this region than the $2.3 \mathrm{~kb} 5^{\prime}$ enhancer. Furthermore, 12.4Ptfla-mCherry expresses more broadly than Ptfla at E14.5, and mCherry expression persists in the dorsal spinal cord and hindbrain after Ptfla is no longer detectable (supplemental Figs. $1 \mathrm{~B}, 6 \mathrm{H}$, available at www.jneurosci.org as supplemental material). In the cerebellum, however, mCherry signal is remarkably absent (Fig. $6 H$ ). Thus, the $12.4 \mathrm{~kb} \mathrm{3'}$ enhancer contains sufficient information to properly activate Ptfla throughout the developing nervous system, excepting the cerebellum. Nonetheless, it lacks information for two important aspects of Ptfla regulation: exclusive spatial expression in cells destined to activate $P t f 1 a$, and a shutoff mechanism restricting its expression temporally to immature neuronal progenitors.

The 3' $12.4 \mathrm{~kb}$ enhancer activates expression independent of Ptf1a No conserved PTF1 sites were identified within the 3' $12.4 \mathrm{~kb}$ enhancer, implying that it functions in a Ptfla-independent manner. This finding is consistent with expression analysis of mCherry and Ptfla described above. To confirm that this element functions independently of Ptfla, we used both gain and loss of function experiments in chick and mouse. We examined whether Ptfla could induce expression through this enhancer in chick as was seen for the 2.3Ptf1a-GFP construct. 12.4Ptf1a-mCherry directs dI4-restricted expression when electroporated into chick neural tube at HH15-16 and examined 48 h later (Fig. 5G). Coelectroporation of a Ptfla expression vector with the enhancer construct did not induce reporter expression outside of the $\mathrm{dP} 4 / \mathrm{dI} 4$ region (Fig. $5 H$ ). We also examined the activity of the 12.4 Ptfla- $m$ Cherry transgene in mice null for Ptf1a. At E10.5, reporter expression is not diminished in either the neural tube or hindbrain of mutant embryos (Fig. 6, compare $E$ with $F$ ). These results verify that the $3^{\prime} 12.4 \mathrm{~kb}$ enhancer contains no autoregulatory activity and does not require Ptfla for its function.

The 3' $12.4 \mathrm{~kb}$ enhancer activates expression independent of ASC/1 Because Ptfla expression is lost at E12.5 in Ascl1-null mice (Mizuguchi et al., 2006), we investigated whether Ascll regulates Ptfla expression through either the $3^{\prime} 12.4 \mathrm{~kb}$ or the $5^{\prime} 2.3 \mathrm{~kb}$ enhancers. A search for Ascll consensus sites (GCAGSTGK) (Gohlke et al., 2008) revealed the presence of two sites in each enhancer within sequence conserved across multiple vertebrate species (http://genome.ucsc.edu/cgi-bin/hgBlat). To test whether Ascl1 could regulate the activity of these enhancers, we used in ovo electroporation to overexpress $A s c l 1$ or an inactive mutant, $A s c l 1^{A Q}$, in the presence of either the $2.3 \mathrm{~kb}$ or $12.4 \mathrm{~kb}$ enhancer (supplemental Fig. 2, available at www.jneurosci.org as supplemental material). As was previously reported, Ascl1 but not Ascl1 ${ }^{\mathrm{AQ}}$ promotes differentiation (Nakada et al., 2004), increasing the lateral migration of electroporated cells. However, even though Ascll was active in this assay, it neither repressed nor activated expression of the Ptfla enhancers. Thus, Ascl1 regulation of Ptfla is not through sequences in the $2.3 \mathrm{~kb} 5^{\prime}$ or $12.4 \mathrm{~kb} 3^{\prime}$ regulatory regions.

\section{Discussion}

Ptfla plays a critical role in establishing a balance of excitatory and inhibitory neurons, and understanding how it is regulated will provide valuable insight not only into nervous system development but also into pathologies in which this balance is disturbed. Here we describe two regulatory elements that control Ptfla expression in the developing nervous system. One of these, the $5^{\prime} 2.3 \mathrm{~kb}$ enhancer, functions via positive autoregulation, as Ptfla is necessary for its activity in vivo. Furthermore, we demonstrate that Ptfla is localized to this regulatory region in vivo, indicating that this activation is direct. Another region, encompassing $12.4 \mathrm{~kb} 3^{\prime}$ of Ptfla, directs proper spatial expression in most neural Ptfla domains. The activity of this enhancer is independent of Ptfla and likely reflects a mechanism responsible for initiating Ptfla expression.

\section{Comparison of Ptfla regulation in the $\mathrm{CNS}$ and pancreas}

These findings parallel those recently reported in the pancreas, where the $2.3 \mathrm{~kb} \mathrm{5}$ ' element is also active (Masui et al., 2008). There, it also directs expression specifically in Ptfla-expressing cells during development. The expression of 2.3Ptf1a-GFP in the pancreas closely follows Ptfla levels; GFP signal is weak during early epithelial growth and intensifies as Ptfla levels accumulate during acinar differentiation (Masui et al., 2008). Collectively, these two studies demonstrate that the highly conserved $2.3 \mathrm{~kb} 5^{\prime}$ Ptfla enhancer functions as a positive autoregulatory enhancer in all Ptfla-expressing regions. They also begin to uncover subtle differences in how Ptfla is regulated in such disparate tissues. For instance, the relatively unconserved $13.4 \mathrm{~kb}$ region between the $2.3 \mathrm{~kb} \mathrm{5}$ enhancer and Ptfla coding region contains sufficient information to direct expression specifically to Ptfla-positive cells in the pancreas, and this expression is synergistic with the 2.3 $\mathrm{kb}$ element (Masui et al., 2008). However, this same region does not express in Ptfla domains in the neural tube, and no synergistic activity is detected with the $2.3 \mathrm{~kb}$ enhancer (see Fig. 1). Furthermore, considering that the $12.4 \mathrm{~kb} \mathrm{3}$ ' enhancer expresses so uniformly in nearly all Ptfla-expressing regions in the nervous 
system, it is surprising that this element expresses very sparsely in the pancreas, and even then it is not active until much later in development (Masui et al., 2008). Clearly distinct mechanisms are responsible for initial activation of $P t f l a$ in the pancreas and neural tissue, while maintenance of Ptfla levels via autoregulation is a highly conserved function.

\section{Role of positive autoregulation of transcription factors}

Positive autoregulation is a common theme in development and is an important regulatory mechanism for many classes of transcription factors. The ability of a factor to self-sustain its levels allows it to become independent from external control, thus committing a cell to a specific identity; for Ptfla, this results in GABAergic neuronal specification in the CNS. Intuitively, feedforward loops should maintain levels ad infinitum, and this is indeed the case for Pit-1 in the pituitary, Barhl1 in the inner ear and CNS, and Ptfla in the pancreas (Chen et al., 1990; Chellappa et al., 2008; Masui et al., 2008). Yet for many other factors involved in cell fate determination, including MyoD, Atoh1, achaete, scute, and Ptfla in the nervous system, self-activation is transient, and expression ceases once cells achieve terminal differentiation (Thayer et al., 1989; Van Doren et al., 1992; Helms et al., 2000). It is possible that for these factors, positive autoregulation functions to achieve a necessary threshold for program initiation rather than to maintain cellular function. In such a scenario, persistence of factors like Ptfla may actually be deleterious by trapping cells in an intermediately differentiated state, a common characteristic of neoplasia. In fact, MyoD, Atoh1, and Ascl1 (the mammalian achaete-scute homolog) are all known to be upregulated in tumors derived from lineages normally expressing these factors (Dias et al., 1990; Ball et al., 1993; Zhao et al., 2008). Therefore, an important component of the Ptflainduced program in maturing neurons must be its own attenuation, where a secondary function in cell maintenance, such as it has in mature acinar cells, does not exist. It seems likely, therefore, that one or more downstream targets of Ptfla in the CNS inhibit its transcriptional activity, thereby breaking its feedforward loop. For other bHLH factors, this is commonly achieved by sequestering E proteins (e.g., with Id and Hes family members) (Sasai et al., 1992; Hirata et al., 2000; Tzeng, 2003), although it remains to be seen whether a similar mechanism exists for Ptfla.

\section{What initiates Ptfla expression}

Autoregulation does not, however, address the question as to how Ptfla transcription is initially activated. The loss of Ptfla expression in the neural tube at E12.5 in Ascl1-null mice suggests that Ascl1 may be involved in this process; however, Ptfla is activated normally before this stage (Mizuguchi et al., 2006; Wildner et al., 2006). It is therefore likely that Ptfla is regulated by distinct mechanisms in $\mathrm{dP} 4$ and $\mathrm{dPL}^{\mathrm{A}}$ progenitors. Furthermore, the role of Ascl1 in regulating Ptfla is not straightforward, as overexpression of Ascl1 during late-stage neurogenesis in the neural tube does not increase Ptfla levels or $\mathrm{dIL}^{\mathrm{A}}$ cell number (Wildner et al., 2006). If Ascll directly regulates Ptfla, it is not acting through the two enhancers studied here (supplemental Fig. 2, available at www.jneurosci.org as supplemental material). Foxn4 has also been shown to regulate Ptf1a, as Foxn4 mutant mice fail to express Ptfla in the retina (Fujitani et al., 2006). However, Foxn4 is not present in the dorsal neural tube or any other Ptfla domain (Li et al., 2005). Thus, it is conceivable that Ptfla expression is controlled in different tissues by factors unique to those tissues.
The $3^{\prime} 12.4 \mathrm{~kb}$ enhancer is a likely candidate to contain the regulatory information for initiation. It expresses strongly in progenitors to Ptf1a-expressing domains, most evident at E12.5, when reporter expression densely labels the ventricular zone (see Fig. $6 C^{\prime}$ ). Still, this element alone cannot account for Ptfla initiation in every domain. In the pancreas, this regulatory element expresses sparsely, and it is completely inactive before acinar formation (Masui et al., 2008). Furthermore, it does not express at any point in the developing cerebellum. What mechanisms initially activate Ptf1a in the pancreas remain unknown; however, a recent study supplies a possible clue into activation of Ptf1a expression in the cerebellum. In this study, the deletion mutant Cbll causes cerebellar agenesis, because of loss of Ptfla only within the cerebellum (Hoshino et al., 2005). The region deleted in this mutant is located $\sim 60-373 \mathrm{~kb}$ downstream of Ptfla and may very well contain cis-regulatory information controlling cerebellum-specific Ptfla expression (Hoshino et al., 2005).

\section{Concluding remarks}

Proper assembly of an organ with such immense complexity as the nervous system requires exquisitely fine control at the molecular level. Not unexpectedly, the genetic circuits responsible for neural development are appropriately intricate. The function of Ptfla in this process seems relatively straightforward, promoting inhibitory neuronal cell fates while suppressing excitatory programs. Nonetheless, even this simple switch requires no fewer than three degrees of temporal control: activation, autoamplification, and termination. Further study of the two regulatory regions presented here will undoubtedly reveal important mechanistic insight into how multiple regions in the nervous system generate the balance of inhibitory and excitatory neurons.

\section{References}

Ball DW, Azzoli CG, Baylin SB, Chi D, Dou S, Donis-Keller H, Cumaraswamy A, Borges M, Nelkin BD (1993) Identification of a human achaete-scute homolog highly expressed in neuroendocrine tumors. Proc Natl Acad Sci U S A 90:5648-5652.

Beres TM, Masui T, Swift GH, Shi L, Henke RM, MacDonald RJ (2006) PTF1 is an organ-specific and Notch-independent basic helix-loop-helix complex containing the mammalian Suppressor of Hairless (RBP-J) or its paralogue, RBP-L. Mol Cell Biol 26:117-130.

Berry N, Jobanputra V, Pal H (2003) Molecular genetics of schizophrenia: a critical review. J Psychiatry Neurosci 28:415-429.

Brinster RL, Chen HY, Trumbauer ME, Yagle MK, Palmiter RD (1985) Factors affecting the efficiency of introducing foreign DNA into mice by microinjecting eggs. Proc Natl Acad Sci U S A 82:4438-4442.

Caspary T, Anderson KV (2003) Patterning cell types in the dorsal spinal cord: what the mouse mutants say. Nat Rev Neurosci 4:289-297.

Chellappa R, Li S, Pauley S, Jahan I, Jin K, Xiang M (2008) Barhl1 regulatory sequences required for cell-specific gene expression and autoregulation in the inner ear and central nervous system. Mol Cell Biol 28:1905-1914.

Chen RP, Ingraham HA, Treacy MN, Albert VR, Wilson L, Rosenfeld MG (1990) Autoregulation of pit-1 gene expression mediated by two cisactive promoter elements. Nature 346:583-586.

Cheng L, Arata A, Mizuguchi R, Qian Y, Karunaratne A, Gray PA, Arata S, Shirasawa S, Bouchard M, Luo P, Chen CL, Busslinger M, Goulding M, Onimaru H, Ma Q (2004) Tlx3 and Tlx1 are post-mitotic selector genes determining glutamatergic over GABAergic cell fates. Nat Neurosci 7:510-517.

Cheng L, Samad OA, Xu Y, Mizuguchi R, Luo P, Shirasawa S, Goulding M, Ma Q (2005) Lbxl and Tlx3 are opposing switches in determining GABAergic versus glutamatergic transmitter phenotypes. Nat Neurosci 8:1510-1515.

Cockell M, Stevenson BJ, Strubin M, Hagenbüchle O, Wellauer PK (1989) Identification of a cell-specific DNA-binding activity that interacts with a transcriptional activator of genes expressed in the acinar pancreas. Mol Cell Biol 9:2464-2476.

Dias P, Parham DM, Shapiro DN, Webber BL, Houghton PJ (1990) Myo- 
genic regulatory protein (MyoD1) expression in childhood solid tumors: diagnostic utility in rhabdomyosarcoma. Am J Pathol 137:1283-1291.

Fields HL, Heinricher MM, Mason P (1991) Neurotransmitters in nociceptive modulatory circuits. Annu Rev Neurosci 14:219-245.

Fujitani Y, Fujitani S, Luo H, Qiu F, Burlison J, Long Q, Kawaguchi Y, Edlund H, MacDonald RJ, Furukawa T, Fujikado T, Magnuson MA, Xiang M, Wright CV (2006) Ptfla determines horizontal and amacrine cell fates during mouse retinal development. Development 133:4439-4450.

Glasgow SM, Henke RM, Macdonald RJ, Wright CV, Johnson JE (2005) Ptfla determines GABAergic over glutamatergic neuronal cell fate in the spinal cord dorsal horn. Development 132:5461-5469.

Gohlke JM, Armant O, Parham FM, Smith MV, Zimmer C, Castro DS, Nguyen L, Parker JS, Gradwohl G, Portier CJ, Guillemot F (2008) Characterization of the proneural gene regulatory network during mouse telencephalon development. BMC Biol 6:15.

Gross MK, Dottori M, Goulding M (2002) Lbxl specifies somatosensory association interneurons in the dorsal spinal cord. Neuron 34:535-549.

Helms AW, Johnson JE (2003) Specification of dorsal spinal cord interneurons. Curr Opin Neurobiol 13:42-49.

Helms AW, Abney AL, Ben-Arie N, Zoghbi HY, Johnson JE (2000) Autoregulation and multiple enhancers control Math1 expression in the developing nervous system. Development 127:1185-1196.

Hirata H, Ohtsuka T, Bessho Y, Kageyama R (2000) Generation of structurally and functionally distinct factors from the basic helix-loop-helix gene Hes3 by alternative first exons. J Biol Chem 275:19083-19089.

Hori K, Cholewa-Waclaw J, Nakada Y, Glasgow SM, Masui T, Henke RM, Wildner H, Martarelli B, Beres TM, Epstein JA, Magnuson MA, Macdonald RJ, Birchmeier C, Johnson JE (2008) A nonclassical bHLH Rbpj transcription factor complex is required for specification of GABAergic neurons independent of Notch signaling. Genes Dev 22:166-178.

Hoshino M, Nakamura S, Mori K, Kawauchi T, Terao M, Nishimura YV, Fukuda A, Fuse T, Matsuo N, Sone M, Watanabe M, Bito H, Terashima T, Wright CV, Kawaguchi Y, Nakao K, Nabeshima Y (2005) Ptfla, a bHLH transcriptional gene, defines GABAergic neuronal fates in cerebellum. Neuron 47:201-213.

Hoveyda N, Shield JP, Garrett C, Chong WK, Beardsall K, Bentsi-Enchill E, Mallya H, Thompson MH (1999) Neonatal diabetes mellitus and cerebellar hypoplasia/agenesis: report of a new recessive syndrome. J Med Genet 36:700-704

Kawaguchi Y, Cooper B, Gannon M, Ray M, MacDonald RJ, Wright CV (2002) The role of the transcriptional regulator Ptfla in converting intestinal to pancreatic progenitors. Nat Genet 32:128-134.

Krapp A, Knöfler M, Frutiger S, Hughes GJ, Hagenbüchle O, Wellauer PK (1996) The p48 DNA-binding subunit of transcription factor PTF1 is a new exocrine pancreas-specific basic helix-loop-helix protein. EMBO J 15:4317-4329.

Krapp A, Knöfler M, Ledermann B, Bürki K, Berney C, Zoerkler N, Hagenbüchle O, Wellauer PK (1998) The bHLH protein PTF1-p48 is essential for the formation of the exocrine and the correct spatial organization of the endocrine pancreas. Genes Dev 12:3752-3763.

Li S, Misra K, Matise MP, Xiang M (2005) Foxn4 acts synergistically with Mash1 to specify subtype identity of V2 interneurons in the spinal cord. Proc Natl Acad Sci U S A 102:10688-10693.

Lumpkin EA, Collisson T, Parab P, Omer-Abdalla A, Haeberle H, Chen P, Doetzlhofer A, White P, Groves A, Segil N, Johnson JE (2003) Math1driven GFP expression in the developing nervous system of transgenic mice. Gene Expr Patterns 3:389-395.

Masui T, Long Q, Beres TM, Magnuson MA, MacDonald RJ (2007) Early pancreatic development requires the vertebrate Suppressor of Hairless (RBPJ) in the PTF1 bHLH complex. Genes Dev 21:2629-2643.

Masui T, Swift GH, Hale MA, Meredith DM, Johnson JE, Macdonald RJ (2008) Transcriptional autoregulation controls pancreatic Ptfla expression during development and adulthood. Mol Cell Biol 28:5458-5468.

McCormick DA, Contreras D (2001) On the cellular and network bases of epileptic seizures. Annu Rev Physiol 63:815-846.

Mizuguchi R, Kriks S, Cordes R, Gossler A, Ma Q, Goulding M (2006) Ascll and Gsh1/2 control inhibitory and excitatory cell fate in spinal sensory interneurons. Nat Neurosci 9:770-778.

Müller T, Brohmann H, Pierani A, Heppenstall PA, Lewin GR, Jessell TM, Birchmeier C (2002) The homeodomain factor Lbxl distinguishes two major programs of neuronal differentiation in the dorsal spinal cord. Neuron 34:551-562.

Müller T, Anlag K, Wildner H, Britsch S, Treier M, Birchmeier C (2005) The bHLH factor Olig3 coordinates the specification of dorsal neurons in the spinal cord. Genes Dev 19:733-743.

Nakada Y, Hunsaker TL, Henke RM, Johnson JE (2004) Distinct domains within Mash1 and Math1 are required for function in neuronal differentiation versus neuronal cell-type specification. Development 131:1319-1330.

Nakhai H, Sel S, Favor J, Mendoza-Torres L, Paulsen F, Duncker GI, Schmid RM (2007) Ptfla is essential for the differentiation of GABAergic and glycinergic amacrine cells and horizontal cells in the mouse retina. Development 134:1151-1160.

Obata J, Yano M, Mimura H, Goto T, Nakayama R, Mibu Y, Oka C, Kawaichi M (2001) p48 subunit of mouse PTF1 binds to RBP-Jkappa/CBF-1, the intracellular mediator of Notch signalling, and is expressed in the neural tube of early stage embryos. Genes Cells 6:345-360.

Pascual M, Abasolo I, Mingorance-Le Meur A, Martínez A, Del Rio JA, Wright CV, Real FX, Soriano E (2007) Cerebellar GABAergic progenitors adopt an external granule cell-like phenotype in the absence of Ptfla transcription factor expression. Proc Natl Acad Sci U S A 104:5193-5198.

Rose SD, MacDonald RJ (1997) Evolutionary silencing of the human elastase I gene (ELA1). Hum Mol Genet 6:897-903.

Sasai Y, Kageyama R, Tagawa Y, Shigemoto R, Nakanishi S (1992) Two mammalian helix-loop-helix factors structurally related to Drosophila hairy and Enhancer of split. Genes Dev 6:2620-2634.

Sellick GS, Barker KT, Stolte-Dijkstra I, Fleischmann C, Coleman RJ, Garrett C, Gloyn AL, Edghill EL, Hattersley AT, Wellauer PK, Goodwin G, Houlston RS (2004) Mutations in PTF1A cause pancreatic and cerebellar agenesis. Nat Genet 36:1301-1305.

Thayer MJ, Tapscott SJ, Davis RL, Wright WE, Lassar AB, Weintraub H (1989) Positive autoregulation of the myogenic determination gene MyoD1. Cell 58:241-248.

Tzeng SF (2003) Inhibitors of DNA binding in neural cell proliferation and differentiation. Neurochem Res 28:45-52.

Van Doren M, Powell PA, Pasternak D, Singson A, Posakony JW (1992) Spatial regulation of proneural gene activity: auto- and cross-activation of achaete is antagonized by extramacrochaetae. Genes Dev 6:2592-2605.

Verma-Kurvari S, Savage T, Gowan K, Johnson JE (1996) Lineage-specific regulation of the neural differentiation gene MASH1. Dev Biol 180:605-617.

Wildner H, Müller T, Cho SH, Bröhl D, Cepko CL, Guillemot F, Birchmeier C (2006) dILA neurons in the dorsal spinal cord are the product of terminal and non-terminal asymmetric progenitor cell divisions, and require Mash1 for their development. Development 133:2105-2113.

Zhao H, Ayrault O, Zindy F, Kim JH, Roussel MF (2008) Post-transcriptional down-regulation of Atoh1/Math1 by bone morphogenic proteins suppresses medulloblastoma development. Genes Dev 22:722-727. 